\title{
STRENGTHENING LOCAL RIVER TRANSPORTATION (KLOTOK) AS RIVER TOURIST ATTRACTION
}

\author{
Mutiani $^{\left.a^{*}\right)}$, M. Adhitya Hidayat Putra ${ }^{a)}$, Ersis Warmansyah Abbas ${ }^{a)}$, \\ Bambang Subiyakto $^{a}$, Ndaru Mukti Oktaviani ${ }^{b)}$ \\ ${ }^{a)}$ Lambung Mangkurat University, Banjarmasin, Indonesia \\ ${ }^{b)}$ Kuningan University, Kuningan, Indonesia \\ ${ }^{*}$ Corresponding Author: mutiani@email.ac.id
}

Article history: received 20 August 2020; revised 28 August 2020; accepted 14 September 2020

\begin{abstract}
Klotok as a river transportation mode is interesting to study. However, not much research focuses on how the role of klotok as a mode of transportation can attract tourists. Klotok becomes an icon as a river tourism icon because it presents a uniqueness for the audience. This study aims to describe how the role of klotok and its existence for the Banjar community. Interviews were conducted with three community groups, namely: klotok owners, traders, and visitors to the Siring Menara Pandang tourist destination. This is intended to provide a complete description of the function of klotok as a mode of water transportation, especially in river areas. The results of the study describe how klotok as a mode of water transportation is moored on the edge of the Martapura River, precisely Siring Menara Pandang. The choice of location is because Siring Menara Pandang is a public space that is used as well as a tourist destination. Revitalizing the river by prioritizing the river as a selling price to tourists has positioned klotok as a vital mode of transportation. Based on its development, klotok not only acts as a mode of river transportation but also as a choice of entertainment attractions for river tourism.
\end{abstract}

Keywords: Klotok; river transportation modes; river tourism

\section{INTRODUCTION}

Culture is understood as a system of knowledge including; ideas or ideas contained in the human mind, so that in everyday life the culture is abstract. The embodiment of culture in the form of objects created by humans as cultured creatures. As the results of a study entitled "Across the River: The Cemetery in Dolina and New Aspects of the Late Urnfield Culture in Croatian Posavina and Northern Bosnia" Explained that culture not only limited to material aspects but also is real, such as patterns of behavior, language, tools of life, social organizations, religion, art, etc. all aimed at helping humans carry out life in society [1].

It should be highlighted that one indicator of the high level of human culture is carrying out activities in the field of water transportation [2]. Thus, this ability can be said to be the oldest form of civilization achieved by humans for decades ago. At that time humans have been able to navigate rivers, ponds, and even the ocean by using water transportation facilities to reach certain places. Although it has been going on for a long time, the field of water transportation is among the oldest civilizations that are still held by humans to this day. Indonesia, which is an islandstudded sea nation, has been carrying out activities in the field of water transportation among its people [3][4][5].

The concept of water transportation essentially carries out transportation with the element of water as the place of operation, in this case, transportation by vehicles carried out in all forms of water territory[6]. In Indonesia, territorial waters refer to areas that hold to the existence of waters in life both in the context of the sea and rivers such as Banjarmasin City. Banjarmasin City is located in the area of Kuala Martapura river which empties into the east side Barito River. The location of the city of Banjarmasin is almost in the middle of Indonesia. Banjarmasin city is located on the east bankBarito river and divided the Martapura River that tipped in Meratus Mountains [7].

Water transportation especially river transportation has become very vital for the people of Banjarmasin (hereinafter referred to as the Banjar community). The vitality of river transportation is documented from the Dutch East Indies era until the 1990s. This period was the era of the glory of river transportation. Types of river transportation such as speedboats, klotok (motorized boats), and jukung (rowing boats) color community activities on the river. But in the development of massive infrastructure, especially the construction of river transportation modes began to be eliminated. This condition led to a policy being rolled out through Banjarmasin mayor regulations to restore the function of the river.

The city of Banjarmasin and label The City of the Thousand River carries the revitalization of the function of the river as an icon of tourism. The length of the Martapura River reaches \pm 25 kilometers. While the overall length reaches 600 kilometers. Formerly the Martapura River was only known as a connecting river and tributary of the Barito River. However, based on Mayor Regulation (PERWALI) Number 25 of 2016 concerning Management and Development of River-Based Tourism has positioned the 
Martapura River to be a destination that is loved by the community to spend leisure time.

Revitalization of river functions is expected to be able to help in the existence of modes river transportation which was eroded by land transportation. This is due to the level of effectiveness and efficiency of land and river transportation cannot be combined [8] [9]. River transportation is timeconsuming and expensive. However, regardless of the perception rolled out by the public, river transportation is part of the attractions of cheap tourist destinations. This study aims to provide a synthesis of how the development of klotok affects the improvement of local tourism.

\section{Definition And Role Of Transfortation}

The basic human fat for movement and the need for goods and services has created a need for transportation. Transportation originates from Discuss Latin "transportare", where is trance means opposite or next door another, and portare means picking up or bring [10]. Transportationad the transfer of goods or passengers from one location to another other, where the product which is moved or moved is needed or desired by that other location [11] [12].

Several factors influence the amount of transportation generation such as income, vehicle ownership, household structure, land value, distance to the center of activity, settlement density, and accessibility [13]. The resurrection then raises the process of travel where there are two types of trips according to Hidayati, namely home-based travel and non-home based travel. Home-based trips are trips where the home is the origin or destination or is the origin and destination point of a trip. While non-home based trips are trips where the home is not the origin or destination point of a trip. For example business trips or shopping that do not come from home or home.

Transportation or travel does not only apply to land but also in waters or rivers. According to Law No. 21 of 1992, it is stated that river, lake and crossing transportation is transportation using ships carried out in rivers, lakes, reservoirs, marshlands, canals, canals, and canals to transport passengers, goods and/or animals organized by river and lake transportation companies whose implementation arranged intra and intermodal integrated which is a unity of the national transportation order and uses fixed and regular routes that are equipped with nonpermanent and irregular routes. The types of river transportation in the city of Jambi include the type of river transportation klotok/ketek with specifications serving freight and passenger transportation for short distance crossings, carrying capacity of $12-15$ people, and is driven by diesel engines. The type of pier/port is still included as a traditional port because it uses wood or improvised pontoon [14]. There are five main elements in transportation, viz [15]:

1. Ada humans, as in need of transportation,

2. Ada goods that humans need,

3. Ada vehicles as means of conveyance,

4. Roads as infrastructure, and

5. O.organization as transportation manager.
Apart from the theoretical exposure to the definition of transportation, it was found an important role both for individuals, the wider community, economic growth, and social politics. Transportation able to create and improve accessibility (degree of accessibility) the potential of natural resources that were not used initially became affordable and can be processed [16]. Progress in transportation will also lead to increased human mobility, where the higher the mobility the higher the level of productivity. Increased productivity has an impact on economic progress. DIn the socio-cultural sector, transportation causes residents and open opportunities for interaction with each other to know and respect each other's culture respectively [17]. Thus, this means it can create community life more diverse and demand for mutual tolerance, in addition to allowing the emergence of variations in space and patterns of human activity [18].

\section{River Transport Policy}

Transportation is a means to move people or goods from one place to another. The process can be done using transportation facilities in the form of vehicles or without vehicles (transported by people) [19]. South Kalimantan has a variety of natural resources. One of the many potential natural resources it has is the river. The river functions as a traffic infrastructure that connects the estuary with the interior, as well as regulating water systems [20]. The river has many vital functions such as water supply, irrigation, electricity generation, navigation, flood control, recreation, fisheries, drainage, and so on [7].

River transportation is transportation that grows and develops naturally in Indonesia due to natural geographical conditions that have many rivers. The road for water transportation besides being natural (sea, river, lake), some are man-made (canals, streams, artificial lakes). This transportation is commonly referred to as "inland water transportation"[21]. Some definitions concerning River and Lake Transportation (ASDP) according to statutory regulations are as follows:

1. Government Regulation Number 82 the Year 1999 concerning Transportation in Water Article 1: River and lake transportation is the activity of transportation using ships carried out in rivers, lakes, reservoirs, marshlands, canals, canals, and channels to transport passengers, goods and/or animals, which organized by river and lake transportation companies.

2. Law Number 21 of 1992 concerning Shipping Article 80 (1): The operation of river and lake transportation is arranged in an integrated intra and intermodal manner which is a unified national transportation order. Article 80 (2): River and lake transportation is carried out using fixed and regular routes that are equipped with irregular and irregular routes.

3. Decree of the Minister of Transportation Number 73 of 2004 concerning the Implementation of River and Lake Transportation Article 2 (4): The area of operation of river and lake transportation includes rivers, lakes, reservoirs, swamps, banks, canals, and canals. 
ASDP is a public transport operator functions as a provider of transportation services for vehicles (goods) and passengers, both intermodal and intramodal transportation. The ASDP system includes:

1. Transport vehicles: riverboats and ferries,

2. Sailing ways: river/lake/ferry signs, river channel dredging, telecommunications, navigation, and inspection vessels,

3. Terminal (port): terminal, warehouse, office, fuel depot, electricity, and water [16].

\section{RESEARCH METHODS}

This study aims to describe the development of river transportation mode in the city of Banjarmasin so that the qualitative approach is used research. The study was conducted in the city of Banjarmasin, precisely on Jalan Piere Tandean Siring Menara Pandang. Research subjects include: Burhan as the owner and head of the Banjarmasin Klotok Association, Sabani, the owner of 8 Klotok in Siring Menara Pandang, Sakrani Klotok owner, Saifullah visitor who works as an employee, Liana the visitor who is a housewife, Nurul Hidayah is a trader who sells every day at Siring Menara Pandang.

The entire research subject was determined by purposive sampling technique. The in-depth interview technique was conducted to dig up data regarding the development of the klotok transportation mode for the Banjar community. Of course, in exploring the data, three steps are carried out, observation along Siring Menara Pandang, and documentation of all activities that occur between klotok owners, visitors, and traders. The Miles and Huberman model is used for data analysis techniques, starting from: (1) data collection; (2) data reduction; (3) data presentation; (4) drawing conclusions and verification. This is intended so that researchers can classify the relationship of research findings in a logical sequence of events. The data validity test technique is needed to see the validity and reliability of the data [22] [23].

Techniques performed (1) Extension of work time and observation in the field. The study was conducted, 21 30 April 2019. However, observations were extended for a week (5 - 11 May 2019). This is done concerning the data needed in the form of a description of public interest in the mode of transportation of the klotok not yet intact (due to changing weather factors), (2) Triangulation (triangulation), is to use the widest variety of sources, methods, from researchers, and theories to provide corroborative evidence. Triangulation becomes a procedure to see the saturation point of data collected [24]. The stages are carried out by comparing the observational data and the results of interviews and the results of study documents and various other sources that support the research objectives [25][26].

\section{RESULTS AND DISCUSSION}

Factually, the geographical condition of the waters is 17,610 square kilometers or $47.62 \%$ of the area of South
Kalimantan. The whole is water that includes all rivers with their branches, lakes and inundation land, beaches that surround a portion of the mainland of South Kalimantan and islands in Pulau Laut district, all kinds of canals, and reservoirs of Aranio. The area of water for the community does not only function for agriculture or fisheries. but equally important is for transportation. Some of these waters are used as transportation routes by residents in south Kalimantan.

Natural physical conditions Banjarmasin City is an area that is drained by large rivers and branches flowing from the north and northeast to the southwest and south. Almost all rivers in the city of Banjarmasin generally empties into the Barito and Martapura rivers whose flow conditions are affected by the tides of the Barito River with an average river length of approximately $5-10 \mathrm{~km}$ and widths varying between 5-60 meters. The river flow pattern can be categorized as a dendritic drainage pattern, where this type of pattern can be characterized from branch river flow to the main river. The city of Banjarmasin itself has the impression of an island or delta formed by the meeting of the Barito River with the Martapura River.

The seasonal climate provides sufficient rainfall, the land surface is crisp and relatively flat, and strong seawater tides cause the water conditions in South Kalimantan to be quite calm. A river, lake, or canal, for example, reaches a range far enough inland to see that the current is still calm enough to facilitate the transportation of it. Transportation traffic in the waters of South Kalimantan using boats and ships is not so difficult because of the flow of water. The river is called Batang or Batang Banyu by the people of South Kalimantan in the Banjar language. The whole river is close to hundreds, from the width of hundreds of meters to the branches of creeks as wide as several meters; from hundreds of kilometers long to several kilometers or fewer kilometers. Therefore,

Martapura River crosses 2 regions, namely: Banjar Regency and Banjarmasin City area. The Martapura River has an overall length of $80 \mathrm{~km}$, while the navigable can be around $45 \mathrm{~km}$ with an average width of $150 \mathrm{~m}$ and the highest water depth of $4 \mathrm{~m}$ and the lowest of $2.4 \mathrm{~m}$. The Martapura River can be sailed by riverboats, both for passenger transportation and for goods and agricultural products and fisheries. The pattern of river transportation networks operating in Banjarmasin City serves two routes, namely: (1) inter-city inter-city river transportation routes, and (2) river transportation routes within the city. The river route for the community is used as a public transportation route. In Banjarmasin, when you want to find the appearance of busy river transportation routes, among others, in the Barito River and Martapura.

Generally, the type of water transportation in South Kalimantan is known by several types, such as; jukung, speedboat, mining, to klotok. This water transportation has been known to the community since before the 1950s [7]. Specifically, Klotok is expected to start appearing in the 1960s, a type of versatile water transportation facility, because it is very popular for people in South Kalimantan, 
replacing the popularity of mining in the previous tempo. Klotok has various functions, according to the needs and activities desired by the owner. That is, there is a special klotok for passenger transportation services, a klotok for goods, trading, fishing, and so on.

At the beginning of its development klotok had almost no difference from the usual form of jukung, only to run it had used a motor (diesel) with a strength of 2-10 PK. That is, klotok time was just a kind of jukung added to the motorbike to run it. Based on the demands of the need for water transportation modes, the klotok is no longer a kind of jukung with additional papa on both sides of the hull and using motorcycles. In just a few years the klotok was then made from a framework consisting of a keel, a height, and a few tusks, then covered with boards. Klotok in this development is already a kind of board boat, different from the jukungg which is a mortar boat. In this way, klotok has changed (modification) from the original form of jukung.

Klotok maintaining the old form is usually used or still looks like to peddle kerosene, coconut oil, rice, and fish. Klotok used for this purpose without using a roof, except for a little part of the stern. The situation is still unchanged and without a body that is painted in the same color as in the shape of a board boat klotok. Types of klotok in the form of board boats that increasingly developed before the 1970s roofed full and walled, painted with a variety of colors, and the rate for passenger transportation services.

Along with the development of the land transportation sector since the 1960s to the last three decades, it has influenced the development of water transportation (klotok). The increased use of built land in the city of Banjarmasin indicates population growth and an increase in the economy which ultimately demands more space to be able to meet all the diverse urban activities. This is what drives the transition of function (conversion) of land from agriculture to non-agriculture.

Klotok No longer loved by passengers. According to Sabani (50) around the year 2010 to 2014, we had been unemployed because there was no pulling klotok. This is because klotok is devoted to passenger transportation services. For the people of Banjar klotok, it is also known as "taxi". However, conditions have begun to change since the Banjarmasin City Government promoted riverbank tourism. Railroad tourism certainly requires a mode of transportation that is available for tourism and passenger service providers. Therefore, then through the City Transportation Office embraced klotok which was once actively attracting passengers in the Basirih area to the old Market.

River transportation routes in the city serve passenger transportation, goods, and trade activities. Data obtained from the South Kalimantan Provincial Transportation Department said that for passenger transportation, the river transportation route in the city serves Banjarmasin-Banua Anyar and Banjarmasin-Mantuil routes. As for the transportation of goods or other trading activities generally to the markets located on the edge of the river. This is because traders more often transport, unload merchandise, and even carry out buying and selling transactions directly from the top of the klotok.

In meaning, the presence of klotok is still considered a public transportation service for passengers. However, the difference is that currently, klotok focuses on the mode of water transportation to reach tourist destination destinations. This is not the same as the past few decades. Klotok is used as a means of transporting merchandise, trading, fishing, and so on. The community is currently using klotok only for modes of transportation to tourist destinations with the sensation of the Banjarmasin river [27]. For the people of Klotok, it acts as an attraction for the public to see and visit tourist attractions because the cost is cheap. In addition to the existence of klotok as evidence of the historical activities of the Banjar community. The use of klotok as a river transportation mode helps showcase the beauty of Banjarmasin's iconic buildings, such as the tower of view, Anno's house, and the Merlion-style probosci's monkey (which can come out of its mouth), traditional markets (Sudimampir and Pasar Lama) and so on.

The development of klotok also experienced ups and downs. Based on the results of research Subiyakto (2005) explained that the river as in the 1950s to 1970s Rivers functioned as a highway. Every day people can be sure that people who are busy going back and forth through one river to another and then out to the larger river. This condition lasted up to two decades. The vitality of river functions encourages transportation activities with the klotok fleet. Conditions have changed since the early 2000s. The popularity of klotok began to fade because it was abandoned by the community. The massive construction of infrastructure (roads) in the New Order era reduced the number of klotok. Based on Asbani's narrative (50 years):

When many motor vehicles were found, our number of passengers declined. The community prefers to use land vehicles using motorized vehicles rather than riding in klotok. At the same time, the road conditions were good, so that a decrease in the number of passengers was felt.

Based on the results of the interview above, it should be noted how the interest of klotok passengers is decreasing every year. The decline was not influenced by natural factors but rather an infrastructure improvements. This decrease resulted in not a few uncle klotok who then did not operate. Not operating klotok indirectly also positioned Banjar culture began to erode. This is based on minimal river functions.

In this regard, the city government evaluated so that the local cultural treasures would not disappear and the uncle's klotok uncle would not lose because he did not have fixed income. Based on UU No. 9 of 2009 concerning tourism states that a tourism destination is a geographical area within one or more administrative regions in which there are tourist attractions, public facilities, tourism facilities, accessibility, and communities which are interrelated and complement the realization of tourism, 
Banjarmasin City then establishes the uniqueness of the tourist attraction.

Banjarmasin City Government then sparked Mayor Regulation (Perda) Number 25 the Year 2016 Article 2 which explains that the purpose of the management and development of river-based tourism is to increase the number of visits and be able to become a means in opening business opportunities [28]. The opening of public space on the riverbanks makes it possible to revive the work of uncle klotok. Klotok Association in Banjarmasin City, currently there are 88 klotok that are active every day. All klotok ( 88 units) has been registered at the Banjarmasin City Transportation Department. They operate the only klotok which has complete mail (route/line).

Current conditions are not given licenses to increase the number of operating klotok unless the owner of the klotok sells route licensing documents to others. The operating klotok is a collection of klotok that used to hold routes (lines) from the Basirih Pier to the Old Market. But now, the whole klotok hang out at three different points namely; Siring Menara Pandang, Siring Bekantan Statue, and Warung Soto Banjar Bang Amat.

To provide certainty for passengers every day the government continues to make infrastructure improvements in public spaces, especially through tourist attractions such as river rafting tours (every day), and floating markets (every weekend). Specifically forThe floating market is known as the Pierre Tandean Floating Market because it is located on Jalan Pierre Tandean. Not only river tourism, but Pierre Tandean Floating Market is also deliberately created and developed as a floating market tourist attraction every weekend to attract the interest of the community. Thus, the life of public spaces through tourist attractions directly becomes a determining factor for the development of klotok in Banjarmasin. Besides, uncle klotok also began to get a stable income every month. Therefore, to maintain income stabilization between Klotok's uncles, the amount of pulling each klotok is regulated by deliberation so as not to cause the roots of conflict between people.

\section{CONCLUSION}

At Siring Menara Pandang social activities can be seen from interactions between klotok owners, traders, and visitors. The development of the river transportation mode in the city of Banjarmasin is strongly influenced by the side of the Banjarmasin City Government then sparked Mayor Regulation Number 25 the Year 2016 Article 2. The rule explains the purpose of the management and development of river-based tourism is to increase the number of visits and be able to be a means of opening business opportunities. Opening of public space through the View Tower on the bank The Martapura River is a transportation mode for klotok back to life. The perception of the Banjar community in Siring Menara Pandang on the mode of transportation of the Klotok river still considered a public transportation service for passengers. However, the difference is that currently, klotok focuses on the mode of water transportation to reach tourist destination destinations. This is not the same as the past few decades. Klotok is used as a means of transporting merchandise, trading, fishing, and so on.

\section{REFERENCES}

[1] L. D. Daria and M. Gavranović "Archaeologia Austriaca Journal," Across River; Cemet. Dol. New Asp. Late Urnf. Cult. Croat. Posav. North. Bosnia, pp. 13-32, 2013.

[2] E. W. Abbas, Pendidikan IPS Berbasis Kearifan Lokal. Bandung: Wahana Jaya Abadi dan FKIPUnlam Press, 2015.

[3] L. Paine, "River Cultures in World HistoryRescuing a Neglected Resource," Fudan J. Humanit. Soc. Sci., pp. 457-472, 2019.

[4] U. Beck, "Varieties of Second Modernity and The Cosmopolitan Vision," Theory, Cult. Soc., pp. 257270, 2016.

[5] M. Harlie, I. Rajiani and E. W. Abbas, "Managing Information Systems By Integrating Information Systems Success Model and The Unified Theory of Acceptance and Usage of Technology," Polish J. Manag. Stud., 2019.

[6] B. Inanloo, B. S. Tansel, K. Jin \& A. Gan "A Decision Aid GIS-Based Risk Assessment and Vulnerability Analysis Approach for Transportation and Pipeline Networks," Saf. Sci., pp. 57-66, 2016.

[7] B. Subiyakto, "Menjadikan Sungai Sebagai Objek Studi," J. Kandil, 2005.

[8] M. Mutiani, "IPS DAN PENDIDIKAN LINGKUNGAN: URGENSI PENGEMBANGAN SIKAP KESADARAN LINGKUNGAN PESERTA DIDIK," SOSIO-DIDAKTIKA Soc. Sci. Educ. J., vol. 4, no. 1, pp. 45-53, 2017.

[9] B. Subiyakto \& Mutiani, "INTERNALISASI NILAI PENDIDIKAN MELALUI AKTIVITAS MASYARAKAT SEBAGAI SUMBER BELAJAR ILMU PENGETAHUAN SOSIAL," Khazanah $J$. Stud. Islam dan Hum., vol. 17, no. 1, pp. 137-166, 2019.

[10] C. N. Fairfax, "Community Practice and The Afrocentric Paradigm," J. Hum. Behav. Soc. Environ., pp. 73-80, 2017.

[11] R. J. Kodoatie, Pengantar Manajemen Infrastruktur (Edisi Revisi). Yogyakarta: Pustaka Pelajar, 2005.

[12] C. Cleophas, C. Cottrill, J. F. Ehmke, and Tierney, "Collaborative Urban Transportation: Recent Advances in Theory and Practice," Eur. J. Oper. Res., pp. 801-816, 2019.

[13] I. N. Hidayati, Bahan Ajar Penginderaan Jauh untuk Studi Perkotaan. Yogyakarta: UGM Press, 2010.

[14] R. P. Sari, Pergeseran Pergerakan Angkutan Sungai di Sungai Martapura Kota Banjarmasin. Semarang: UNDIP (Tesis Tidak Diterbitkan), 2008.

[15] A. Munawar, Dasar-dasar Teknik Transportasi. Yogyakarta: Beta, 2005. 
[16] M. N. Nasution, Manajemen Transportasi (Edisi Kedua). Jakarta: Ghalia Indonesia, 2004.

[17] H. A. Salim, Manajemen Transportasi. Jakarta: Grafindo, Raja, 2002.

[18] E. K. Morlok, Pengantar Teknik dan Perencanaan Transportasi. Jakarta: Erlangga, 1998.

[19] B. Wetzstein, R. Florax, K. Foster and J. Binkley, "Transportation Costs: Mississippi River Barge Rates," J. Commod. Mark., pp. 100-123, 2020.

[20] T. H. Ariwibowo, "Sungai Pumpung Antara Kehidupan Dan Urusan Hidup," J. Kebud. Kandil, 2005.

[21] A. T. Mulyana, "Transportasi Air," In Diktat Kuliah. Fakultas Tehnik Universitas Lambung Mangkurat, Banjarmasin, 2005.

[22] J. W. Creswell, Research Design: Pendekatan Kualitatif, Kuantitatif, dan Mixed. Yogyakarta: PT Pustaka Pelajar, 2010.

[23] K. A. Richards and M. A. Hemphill, "A Practical Guide to Collaborative Qualitative Data Analysis," J. Teach. Phys. Educ., pp. 225-231, 2018.

[24] R. K. Yin, Case Study Research: Desain and Methods (Applied Social Research Methods). Illinois: Sage Publication. Inc, 2008.

[25] B. Bungin, Metodologi Penelitian Kualitatif Aktualisasi Metodologis ke Arah: Ragam Varian Kontemporer. Jakarta: Rajawali Press, 2001.

[26] N. K. Denzin and Y. S. Lincoln, HandBook of Qualitative Research. Yogyakarta: Pustaka Pelajar, 2009.

[27] B. Subiyakto, M. Mutiani and M. A. H. Putra, Pergeseran Makna Klotok Bagi Masyarakat di Aliran Sungai Martapura. Banjarmasin: FKIP ULM, 2019.

[28] A. Ajidayanti and E. W. Abbas, "Utilization of Tourism Bekantan Mascot as a Learning Resource On Social Studies," Innov. Soc. Stud. J., vol. 1, no. 1, pp. 78-86, 2019. 